\title{
HIV Diversity and Classification, Role in Transmission
}

\author{
Duri Kerina $^{1^{*}}$, Stray-Pedersen Babill ${ }^{2}$, F. Muller ${ }^{3}$ \\ ${ }^{1}$ Department of Immunology, University of Zimbabwe, Harare, Zimbabwe; ${ }^{2}$ Division of Women and Children, Oslo University Hos- \\ pital, Rikshospitalet and Institute of Clinical Medicine, University of Oslo, Oslo, Norway; ${ }^{3}$ Department of Microbiology, University \\ of Oslo and Oslo University Hospital, Rikshospitalet, Oslo, Norway. \\ Email: *kerina.duri@yahoo.com
}

Received November $1^{\text {st }}$, 2012; revised December $18^{\text {th }}, 2012$; accepted January $19^{\text {th }}, 2013$

Copyright (C) 2013 Duri Kerina et al. This is an open access article distributed under the Creative Commons Attribution License, which permits unrestricted use, distribution, and reproduction in any medium, provided the original work is properly cited.

\begin{abstract}
The hallmark of HIV-1 is its extensive genetic diversity that emanates mainly from high mutations. Phylogenetically, HIV can be classified into geographically confined groups, types, subtypes and circulating recombinant forms (CRFs) that are however subject to change over time. HIV genetic diversity may partially explain the observed heterogeneity in HIV prevalence and has also been reported to impact on viral transmissibility and differential rates of disease progression. The aim of this review is to present a simple overview of the principles and concepts of HIV diversity and classification. Tracking the presence of new HIV strains is not only important for surveillance purposes but is also critical in facilitating personalized targeted therapy as well as forming the basis for development of the much anticipated effective vaccines against this scourge.
\end{abstract}

Keywords: HIV; Diversity; Classification; Transmission

\section{Introduction}

\subsection{HIV-1 Genetic Diversity}

The unique characteristics of human immunodeficiency virus type 1 (HIV-1) are its extensive genetic diversity [1-4]. Diversification is due to errors encountered during viral replication including host immune response selection pressures. Diversity is manifested as sequence variability particularly within the env variable (V) regions [5]. Variability not only makes it difficult for the immune system to identify the virus but it also facilitates the rapid viral immune escape. The high level of genetic diversity has important implications in screening, diagnostic testing, disease monitoring and treatment outcomes [6-14]. Questions have been raised on whether diversity may also affect viral transmissibility and pathogenicity [1520]. Sadly, genetic diversity has been the major impediment in the effective vaccine design and development since the human immune response to HIV is strain-specific [21]. Four factors vis-a-viz, the infidelity of reverse transcriptase (RT), recombination, superinfection and high replication rate of the virus have been shown to contribute to the development of the extensive HIV genetic variation $[22,23]$.

\footnotetext{
"Corresponding author.
}

\subsection{Properties of RT Enzyme and Recombination}

The infidelity of HIV RT enzyme confers mutations at an approximate rate of one error per genome per replication cycle [24]. RT also accounts for genomic heterogeneity in progeny viruses through its role in recombination. Genetic recombination is an evolutionary strategy for survival in a changing environment for viral variants with superior fitness at an average of $1.38 \times 10^{-4}$ recombination events/adjacent sites/generation in vivo [25]. It occurs when an individual is co-infected with at least two different HIV strains that are multiplying concurrently in the same cell [26,27]. It is caused by high selection pressure from either the natural host immune response or antiretroviral drugs [28]. Recombinants between highly similar HIV-1 strains occur at highest frequencies while that between distant HIV-1 strains happen at very low frequencies [29]. Dual and even triple HIV-1 infections have been reported [30,31]. HIV superinfections also allow a mechanism for genetic recombinants between distant variants [32-37]. Superinfection and co-infection which both involve reinfection by at least two genetically distinct viral variants differ based on whether the second infection is contracted prior to or after the primary host immune response has been mounted [38]. These are as- 
sociated with high viral loads and accelerated rates of disease progression [39,40]. HIV-1 superinfection presents an additional concern to the already challenging problem of HIV-1 vaccine design in the face of the virus's rapid evolution [41].

\subsection{High Turnover Rates of HIV-1 in Vivo}

HIV-1 virions are produced and cleared at an extremely rapid pace. Since the HIV-1 genome is about $10^{3}$ base pairs in length, then the baseline rate of viral production is approximately $10^{10}$ virions per day [42]. This rapid turnover has been considered as the major factor underlying the pathogenesis of HIV/AIDS alongside with the destruction of CD4+ T-helper lymphocytes [42]. Besides the viral RT, host RNA polymerase II makes minimal contributions to retroviral frame shift mutations [43].

Diversity may also be enhanced by different genetic factors including HLA in patients from different regions of the world. Viral genetic factors include proteins such as Tat, Vif and Rev that interact with human genetic factors such as APOBEC, langerin, tetherin and CCR5 and HLA B27, B57, DRB1*1303, KIR and PARD3B [44]. The inability of Vif to counteract host APOBEC3 proteins lead to the deamination of cytidine to uridine consequently causing viral guanosine to adenosine hypermutations [45]. Some error causing mechanisms contributing to HIV-1 variation are shown in Figure 1.

Genetic diversity helps the virus evade the immune system and consequently this viral heterogeneity allows for a quick adaptation to the human immune system, antiretroviral drugs, or both leading to viral fitness/positive selection in the face of pharmacologic or immunologic selection pressures [47]. Every day millions of genetic variants accumulate in latently infected cells only to be reactivated at some time in the future [48]. Thus, the extensive diversity of HIV resulting in a myriad of
HIV variants has necessitated the need for its classification. This taxonomy facilitates better utilization of the ever growing viral sequence database through comparison with previously published work.

\subsection{Classification of HIV}

HIV-1 strains are not randomly distributed across the globe but they display a distinctive geographical distribution [49]. Prior to 1992, HIV-1 strains were classified into two main classes on the basis of their respective geographical origin being then, the North American and African variants [50]. Thus, HIV variation is highest among viruses from different geographical locations, higher among isolates from different individuals. However, variants present as relatively similar quasi-species within the same individual [51,52]. A quasi-species is a cloud or swarm of genetically diverse variants that are linked through mutations that interact cooperatively on a functional level but collectively contributing to the characteristics of a population [53].

With the advent of phylogenetic analysis the env gene has revealed the existence of multiple phylogenetic clusters that were used in the compilation of the $1992 \mathrm{HIV}$ classification compendium based on envelope viral sequence similarities $[54,55]$. As the env sequence database increased over the years the gag and pol gene sequences were also incorporated in the classification procedure consequently, identifying HIV types, groups, subtypes, sub-subtypes and circulating recombinant forms (CRFs) [4,56-68], as summarised in Figure 2.

\subsubsection{HIV Types}

Phylogenetically HIV can be classified into two types; type 1 (HIV-1) and type 2 (HIV-2) [65]. Both viral types cause AIDS. HIV-1 is the first in the class of human retroviruses and accounts for most of the world's HIV in-

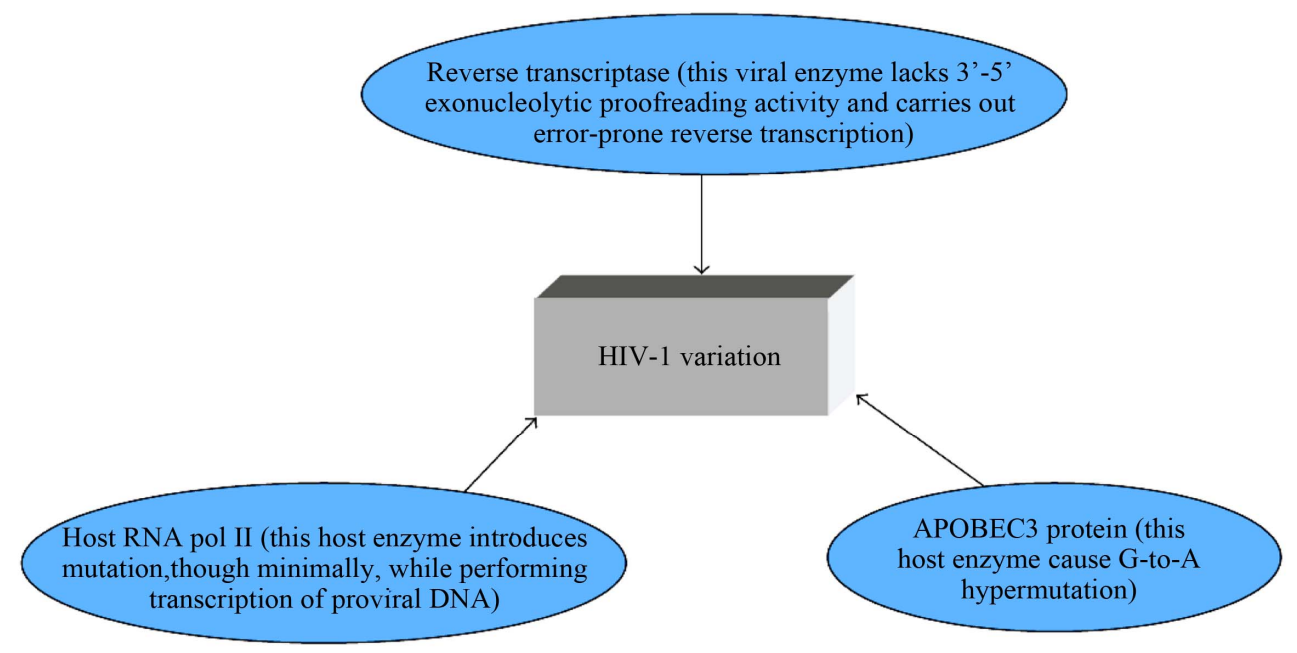

Figure 1. A schematic sketch of error-causing machinery causing HIV-1 genetic diversity [46]. 


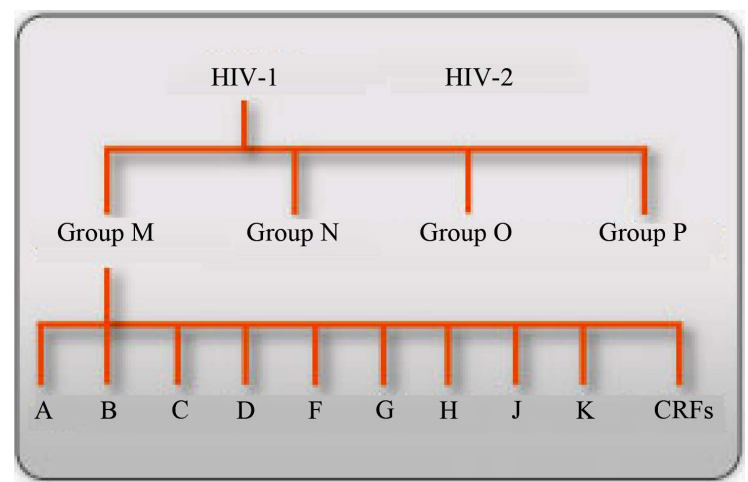

Figure 2. Summary of HIV classification: adopted from reference [69].

fections. Its origin can be traced back to a Simian Immunodeficiency Virus (SIV) isolated from a Chimpanzee (cpz) sub-species, Pan troglodytes troglodytes (SIVcpz) cross species transmission to humans [70-72]. HIV-2 is the second in the same class of human retroviruses but is largely confined to West Africa. The primate reservoir of HIV-2 is sooty mangabey, Cercocebus atys (green monkey) $[73,74]$. Thus, (SIVCPZ) is closely related to HIV-1, while SIV from sooty mangabey (SIVSM) is closest to HIV-2 [75]. HIV-1 and HIV-2 are closely related viruses with nucleotide sequence homology of 58\%, 59\% and $39 \%$ in the gag, pol and env genes, respectively [76]. Despite similar modes of transmission, HIV-2 is not as efficient in transmission horizontally and vertically [65,77,78]. Relative to HIV-1, HIV-2 has a reduced rate of disease development and has shown natural resistance to readily available non-nucleoside reverse transcriptase inhibitors (NNRTIs) [79]. Genetic recombination between HIV types-1 and-2 has been reported [80]. Distinction of HIV types is essential for accurate surveillance, diagnosis as well as administration of appropriate antiretroviral therapies.

\subsubsection{HIV Groups}

Phylogenetic analysis of HIV-1 suggested that zoonosis occurred on at least three independent cross species transmission events from chimpanzee, Pan troglodytes (pts), Pan troglodytes troglodytes (ptts) or gorilla (gor) resulting in four distinct HIV groups called the major (M), outlier (O), non-M/non-O (N) as shown in Figure 3. Studies have estimated the timing for the zoonosis of each lineage of groups M, O, and N at around 1931, 1920 and 1963, respectively [82]. Group $M$ is responsible for more than $90 \%$ of the world HIV infections [83]. Interestingly, the genetic analysis of sequences from clinical materials obtained from members of a Norwegian family infected earlier than 1971 showed that they carried viruses of the group $\mathrm{O}$ mainly restricted to West Africa [84]. HIV groups have genetic sequence differences of $>40 \%$ in some coding regions [85]. More recently, a

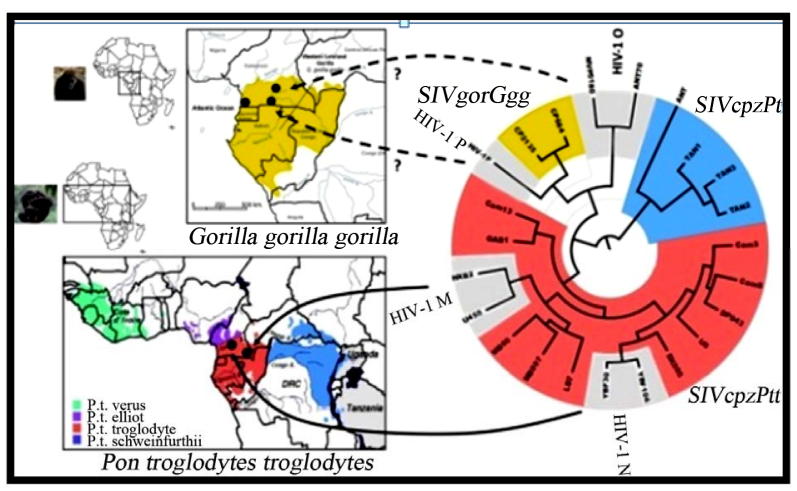

Figure 3. Evolutionary relationships of HIV groups. SIVcpzPts (blue), SIVcpzPtt (red), SIVgor (yellow), and HIV-1 group $M, N, O$, and $P$ (gray) strains based on partial env (gp41) sequences. Arrows indicate the ape reservoirs to the different HIV groups. Dotted arrows indicate that the direct reservoirs for $\mathrm{HIV}-1$ groups $O$ and $P$ remain elusive [81].

new putative group, designated $\mathrm{P}$, was reported in France from a Cameroonian female immigrant [86]. Group P viral sequences have been shown to form a distinct HIV-1 lineage with SIV sequences from western gorillas (SIVgor; Gorilla gorilla gorilla), suggesting that group $P$ originated from gorillas [87] Reports have indicated that HIV-1 group $\mathrm{P}$ infections are rare, accounting for only $0.06 \%$ of HIV infections in Cameroon [88].

Unlike groups $\mathrm{O}, \mathrm{N}$ or $\mathrm{P}$, group $\mathrm{M}$ has been classified into subtypes.

\subsubsection{HIV-1 Subtypes}

Subtypes are phylogenetically linked strains of HIV-1 that are approximately the same genetic distance from one another. Group $\mathrm{M}$ has been classified into nine distinct subtypes, also called clades or genotypes, denoted with letters, A, B, C, D, F, G, H, J and K, thus making the development of effective blanket diagnostic and monitoring tests or vaccine a challenge [84,89]. Intersubtype variation is about $30 \%$ with respect to the env gene sequence and $15 \%$ for both the gag and pol genes sequences [90]. Different risk groups for HIV infection are associated with specific subtypes with intravenous drug users (IDUs) including the gay communities and heterosexual population generally acquiring subtype $B$ and non-B subtypes, respectively [91-93].

\subsubsection{HIV-1 Sub-Subtypes}

Within each subtype numerous HIV-1 variants exist that exhibit minor intra-subtype genetic diversity of within $10 \%$ called sub-subtypes [94]. These are distinctive HIV-1 lineages that are closely related to a particular subtype lineage, but are not genetically distant enough to justify calling them new subtypes. Sub-subtypes are denoted by numerals for instance in the case for subtype A 
these have been named A1, A2 or A3 [95]. Recent studies have demonstrated the need for HIV classification using full-length genomic sequences if new distinctive subtypes are to be accurately identified rather than relying on sequencing of different viral gene fragments as has been the standard.

\subsubsection{HIV Recombinants}

Full genome sequencing of HIV has resulted in the discovery of circulating and unique recombinant forms (CRFs) and URFs, respectively. Recombinants are unique in the sense that they may be described in isolated individuals without any evidence of epidemic spread. To be classified as a CRF, a virus strain must be detected in at least three epidemiologically unlinked individuals and must be capable of establishing an epidemic on its own. Thus, these mosaic HIV-1 strains reflecting a mixture of subtypes circulating in different populations may have altered pathogenic and/or transmissibility properties [96]. CRFs are referred to by their number that is assigned according to the order of their discovery and the respective subtypes involved for example CRF02_AG or by their number(s) followed by the letters "cpx" (for complex), when more than two subtypes are involved for example CRF04_cpx or CRF06_cpx [97]. One of the most common group $\mathrm{M}$ CRFs is $\mathrm{A} / \mathrm{E}$, previously described as subtype E in Southeast Asia but was later renamed CRF01_AE following full HIV genome sequencing [98]. To date about $21 \mathrm{CRFs}$ and several URFs have been described [99]. All CRFs together account for $18 \%$ of the world's HIV-1 infections [100]. HIV-1 subtypes and recombinants may differ with respect to viral load levels [101], transcriptional activation levels, disease progression and response to antiretroviral therapy including drug induced/natural resistance patterns [102-105].

\subsection{Distribution of HIV-1 Subtypes and Recombinants}

Over 50 different subtypes and CRFs have been described [106,107]. Subtype B is geographically confined to North America, Western Europe and Australia. See Figure 4. Paradoxically subtype B is quite rare in Africa, the purported origin of HIV. Global proportions of HIV-1 subtypes and recombinants have shown that subtype $\mathrm{C}$ accounts for more than $50 \%$ of world's infections followed by $12 \%, 10 \%, 6 \%$ and $3 \%$ for subtypes A, B, G and D respectively whilst subtypes $\mathrm{F}, \mathrm{H}, \mathrm{J}$ and $\mathrm{K}$ together account for about $0.94 \%$ of all the infections [90]. CRF01_AE and CRF02_AG are each responsible for 5\% of infections while CRF03_AB is responsible for $0.1 \%$ of global infections with the other recombinants contributing to the remaining $8 \%$ of all HIV infections [90].

In most Southern African nations subtype C predominates, contributing $93 \%$ - $100 \%$ of the HIV-1 infections amongst individual countries [90,109]. Interestingly, the greatest diversity of subtypes and recombinants is present in Central Africa, Central African Republic, Gabon, Angola and Chad harboring only about 5\% of the world's infected individuals [109]. Thus a general observation is that a higher diversity of subtypes is associated with relatively slower epidemics whilst explosive epidemics generally have only one prevalent subtype.

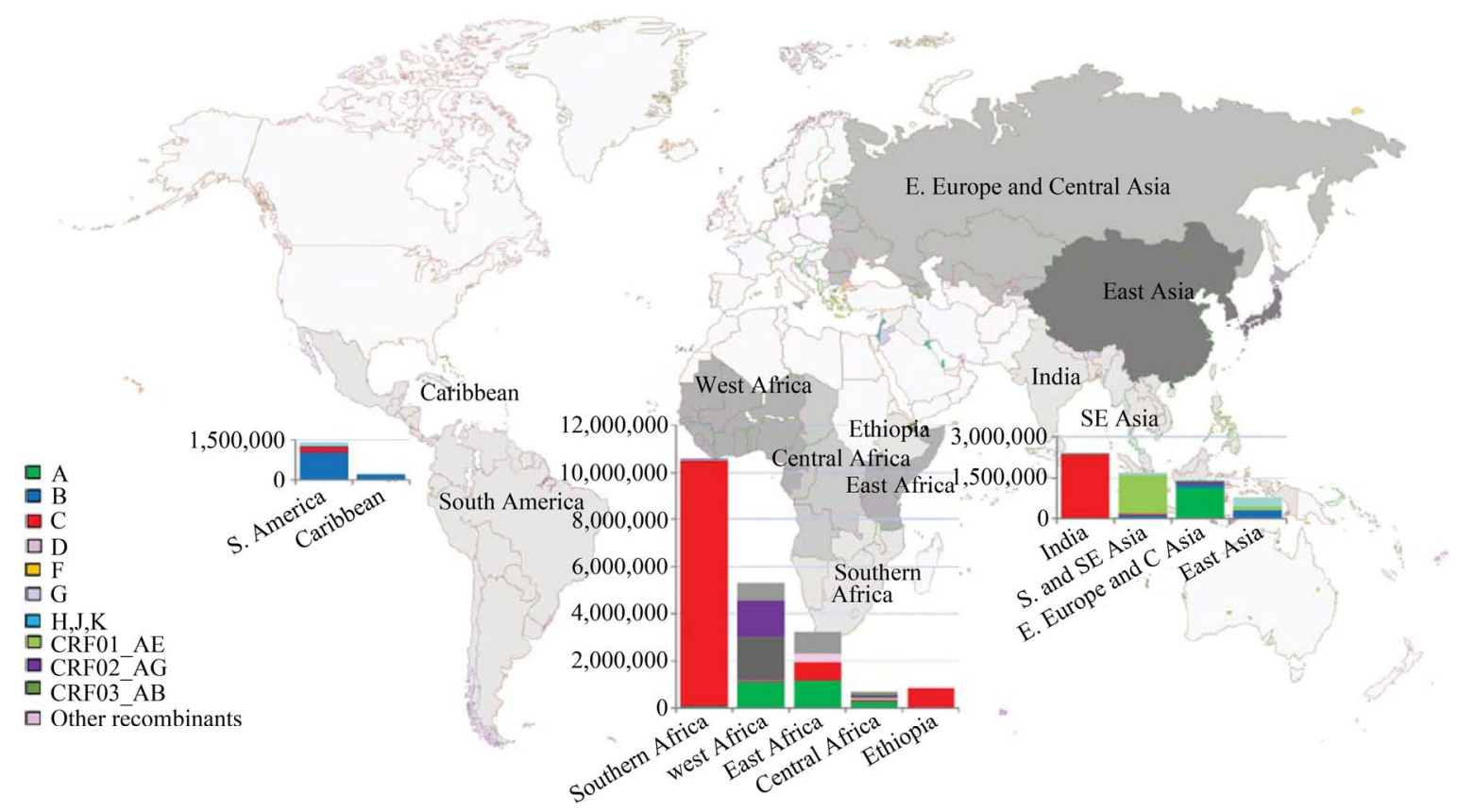

Figure 4. Global distribution of HIV-1 subtypes and recombinants [108]. 
1.5.1. Subtypes Trends and Distribution in Zimbabwe Previous Zimbabwean studies in the 1990s and early 2000 have observed a predominant subtype C [110-112]. The origins and evolutionary history of HIV-1 subtype C in Zimbabwe with respect to the $\mathrm{pol}$ sequence data sets generated from four sequential cohorts of antenatal women in Harare, from 1991-2006 has demonstrated increasing sequence divergence over the 15 -year period. This data also indicates a most recent common ancestor date of around 1973 with three epidemic growth phases: an initial slow phase (1970s) followed by exponential growth (1980s), and a linearly expanding epidemic to the present day [113]. However, current HIV subtype(s) distribution in Zimbabwe remain elusive in view of the influence of the population movements in the past decade as result of the economic meltdown which could have facilitated subtype inter mixing. Generally, subtype specific variations may exist that influence differential transmissibility in different regions [114-116].

\subsubsection{HIV Diversity, Transmission and Disease Progression}

Following sexual transmission of HIV the virus initially replicates locally in the vaginal or rectal mucosa [117]. Genetic diversity of HIV is lost during horizontal transmission and the virus gradually evolves towards a common ancestral sequence once in the new host $[15,118]$. Newly infected subjects acquire a subset of the viruses that were circulating in the transmitting partner; transmitted variants have less diversity and divergence [119]. Studies have correlated high HIV replication capacity with increased transmission rates [120]. Understanding the quantitative relationship between plasma HIV-1 RNA and HIV-1 transmission risk has been the cornerstone for ART preventive interventions that strive to reduce plasma HIV-1 levels that in turn reduce the risk of HIV-1 transmission [121]. Interestingly, Langerhans cells have shown minimal susceptibility to infection with subtype B virus but substantially greater sensitivity for infections by subtype C [122]. In the Rakai, Ugandan study, subtype A viruses have been shown to have a significantly higher rate of heterosexual transmission relative to subtype $\mathrm{D}$ viruses [123]. Differential subtype transmission efficiency may be important for HIV vaccine evaluation especially for the subtype-specific HIV epidemics in SSA. HIV-1-discordant couples are increasingly viewed as a valuable source of participants for HIV vaccine and prevention trials [124]. Curiously HIV-1 subtype C has been found to be the predominant subtype in sero-discordant couples followed by subtypes B and A, respectively [125].

Increasing HIV-1 replication efficiency has also been related to a concomitant increase in HIV-1 diversity, which in turn has been the determining factor in disease progression [126,127]. Non-A subtype infections have been shown to progress to AIDS faster than those infected with subtype A [128]. More so subtype D has been associated with the most rapid disease progression relative to subtypes A, C and CRFs [129-131]. Pregnancy has been shown to increase the risk of female-to-male HIV-1 transmission by two folds [132]. Pregnant women infected with subtype $C$ have been shown to significantly shed more HIV-1-infected vaginal cells than were those infected with subtype A or D [133]. Increased HIV-1 shedding has been correlated with a more complex population of HIV-1 quasi-species in the genital tracts of parturient women, which may increase the probability of transmission of fetotropic strains [134]. Identifying the specific genetics characteristics of successfully transmitted variants is also paramount in the development of an effective vaccine. Subtype and CRFs determination is generally done using the gag/env heteroduplex mobility assay (HMA) originally developed by Delwart [135] and later modified by Heyndrick et al., in the year 2000 [136]. Whole genome sequencing remains the gold standard although partial sequencing also gives good results at reasonable cost.

\section{Conclusion}

The geographic distribution of subtypes is subject to constant change. Recombinant forms of the virus will continue to appear as long as the different subtypes of HIV-1 continue to circulate between continents and recombination continues to occur. With the world fast becoming a global village new HIV strains are emerging in areas where they were originally non-existent. Thus importation and exportation of new types, subtypes and even CRFs of HIV is possible. The risky behaviour of military personnel plus high HIV-1 sero-prevalence within this group may have facilitated the introduction of new HIV types, subtypes or recombinants within the armed forces themselves and to the general population both at home and abroad. Tracking the presence of new HIV strains is important for surveillance purposes, effective chemotherapy, diagnosis and disease monitoring including vaccine design and development. In the absence of effective prophylactic HIV vaccines, behavior change remains the key to successful prevention efforts.

\section{Acknowledgements}

We are grateful to Letten Foundation of Oslo, Norway for the sponsorship.

\section{REFERENCES}

[1] R. M. Lynch, T. Shen, S. Gnanakaran and C. A. Derdeyn, “Appreciating HIV Type 1 Diversity: subtype Differences 
in Env," AIDS Research and Human Retroviruses, Vol. 25, No. 3, 2009, pp. 237-248. doi:10.1089/aid.2008.0219

[2] F. McCutchan, E. K. Viputtigul, M. S. de Souza, J. K. Carr, L. E. Markowitz, P. Buapunth, et al., "Diversity of Envelope Glycoprotein from Human Immunodeficiency Virus Type 1 of Recent Seroconverters in Thailand," AIDS Research and Human Retroviruses, Vol. 16, No. 8, 2000, pp. 801-805. doi:10.1089/088922200308792

[3] F. E. McCutchan, A. W. Artenstein, E. Sanders-Buell, M. O. Salminen, J. K. Carr, J. R. Mascola, et al., "Diversity of the Envelope Glycoprotein among Human Immunodeficiency Virus Type 1 Isolates of Clade E from Asia and Africa," Journal of Virology, Vol. 70, No. 6, 1996, pp. 33313338.

[4] F. E. McCutchan, M. O. Salminen, J. K. Carr and D. S. Burke, "HIV-1 Genetic Diversity,” AIDS, Vol. 10, Suppl. 3, 1996, pp. S13-S20. doi:10.1097/00002030-199601001-00003

[5] D. Almond, T. Kimura, X. Kong, J. Swetnam, S. ZollaPazner and T. Cardozo, "Structural Conservation Predominates over Sequence Variability in the Crown of HIV Type 1's V3 Loop," AIDS Research and Human Retroviruses, Vol. 26, No. 6, 2010, pp. 717-723. doi:10.1089/aid.2009.0254

[6] J. M. Mercado, D. R. Di and M. G. Pradal, "Genetic Diversity of HIV-1 Subtype F from Brazil: Failure of HIV-1 Viral Load Testing Based on Molecular Biology Amplification Methods,” AIDS, Vol. 1, No. 15, 1999, pp. 21832185. doi:10.1097/00002030-199910220-00032

[7] B. G. Brenner, M. Oliveira, F. Doualla-Bell, D. D. Moisi, M. Ntemgwa, F. Frankel, et al., "HIV-1 Subtype C Viruses Rapidly Develop K65R Resistance to Tenofovir in Cell Culture,” AIDS, Vol. 20, No. 9, 2006, pp. F9-F13. doi:10.1097/01.aids.0000232228.88511.0b

[8] J. P. Clewley, "Genetic Diversity and HIV Detection by PCR,” Lancet, Vol. 346, No. 8988, 1995, p. 1489. doi:10.1016/S0140-6736(95)92505-8

[9] "Diversity of HIV Strains Impacts Diagnostic Test Accuracy,” AIDS Patient Care STDS, Vol. 23, No. 3, 2009, p. 220.

[10] C. Apetrei, I. Loussert-Ajaka, D. Descamps, F. Damond, S. Saragosti, F. Brun-Vezinet, et al., "Lack of Screening Test Sensitivity during HIV-1 Non-Subtype B Seroconversions,” AIDS, Vol. 10, No. 14, 1996, pp. F57-F60. doi:10.1097/00002030-199612000-00002

[11] M. S. Cohen, C. L. Gay, M. P. Busch and F. M. Hecht, "The Detection of Acute HIV Infection," The Journal of Infectious Diseases, Vol. 202, Suppl. 2, 2010, pp. S270S277. doi:10.1086/655651

[12] H. Bolivar, R. Geffin, G. Manzi, M. A. Fischl, V. Holzmayer, W. B. Mak, et al., "The Challenge of HIV-1 Genetic Diversity: Discordant CD4+ T-Cell Count and Viral Load in an Untreated Patient Infected with a Subtype F Strain,” Journal of Acquired Immune Deficiency Syndromes, Vol. 52, No. 5, 2009, pp. 659-661. doi:10.1097/QAI.0b013e3181b72539

[13] B. Julg and F. D. Goebel, "HIV Genetic Diversity: Any Implications for Drug Resistance?” Infection, Vol. 33, No.
4, 2005, pp. 299-301. doi:10.1007/s15010-005-6405-1

[14] S. Spira, M. A. Wainberg, H. Loemba, D. Turner and B. G. Brenner, "Impact of Clade Diversity on HIV-1 Virulence, Antiretroviral Drug Sensitivity and Drug Resistance," Journal of Antimicrobial Chemotherapy, Vol. 51, No. 2, 2003, pp. 229-240. doi:10.1093/jac/dkg079

[15] C. T. Edwards, E. C. Holmes, D. J. Wilson, R. P. Viscidi, E. J. Abrams, R. E. Phillips, et al., "Population Genetic Estimation of the Loss of Genetic Diversity during Horizontal Transmission of HIV-1,” BMC Evolutionary Biology, Vol. 6, 2006, p. 28. doi:10.1186/1471-2148-6-28

[16] A. Lange and N. M. Ferguson, "Antigenic Diversity, Transmission Mechanisms, and the Evolution of Pathogens," PLOS Computational Biology, Vol. 5, No. 10, 2009, Article ID: e1000536. doi:10.1371/journal.pcbi.1000536

[17] M. A. Papathanasopoulos, G. M. Hunt and C. T. Tiemessen, "Evolution and Diversity of HIV-1 in Africa-A Review,” Virus Genes, Vol. 26, No. 2, 2003, pp. 151-163. doi:10.1023/A:1023435429841

[18] D. M. Tebit, I. Nankya, E. J. Arts and Y. Gao, "HIV Diversity, Recombination and Disease Progression: How Does Fitness 'Fit' into the Puzzle?” AIDS Reviews, Vol. 9, No. 2, 2007, pp. 75-87.

[19] H. Zhang, D. C. Tully, F. G. Hoffmann, J .He, C. Kankasa and C. Wood, "Restricted Genetic Diversity of HIV-1 Subtype C Envelope Glycoprotein from Perinatally Infected Zambian Infants,” PLoS One, Vol. 5, No. 2, 2010, Article ID: e9294. doi:10.1371/journal.pone.0009294

[20] M. S. Saag, S. M. Hammer and J. M. Lange, "Pathogenicity and Diversity of HIV and Implications for Clinical Management: A Review," Journal of Acquired Immune Deficiency Syndromes, Vol. 7, Suppl. 2, 1994, pp. S2-S10.

[21] R. B. Lal, S. Chakrabarti and C. Yang, "Impact of Genetic Diversity of HIV-1 on Diagnosis, Antiretroviral Therapy \& Vaccine Development," Indian Journal of Medical Research, Vol. 121, No. 4, 2005, 287-314.

[22] S. Bonhoeffer, E. C. Holmes and M. A. Nowak, "Causes of HIV Diversity,” Nature, Vol. 376, No. 6536, 1995, p. 125. doi:10.1038/376125a0

[23] Y. Takebe, "HIV-1 Genetic Diversity: Mechanism and Its Biological Implication,” Uirusu, Vol. 51, No. 2, 2001, pp. 123-134. doi:10.2222/jsv.51.123

[24] R. B. Oelrichs, I. L. Shrestha, D. A. Anderson and N. J. Deacon, "The Explosive Human Immunodeficiency Virus Type 1 Epidemic among Injecting Drug Users of Kathmandu, Nepal, Is Caused by a Subtype C Virus of Restricted Genetic Diversity,” Journal of Virology, Vol. 74, No. 3, 2000, pp. 1149-1157. doi:10.1128/JVI.74.3.1149-1157.2000

[25] D. Shriner, A. G. Rodrigo, D. C. Nickle and J. I. Mullins, "Pervasive Genomic Recombination of HIV-1 in Vivo," Genetics, Vol. 167, No. 4, 2004, pp. 1573-1583. doi:10.1534/genetics.103.023382

[26] G. Fang, B. Weiser, C. Kuiken, S. M. Philpott, S. Rowland-Jones, F. Plummer, et al., "Recombination Following Superinfection by HIV-1,” AIDS, Vol. 18, No. 2, 2004, 
pp. 153-159. doi:10.1097/00002030-200401230-00003

[27] A. Machuca, S. Tang, J. Hu, S. Lee, O. Wood, C. Vockley, et al., "Increased Genetic Diversity and Intersubtype Recombinants of HIV-1 in Blood Donors from Urban Cameroon," Journal of Acquired Immune Deficiency Syndromes, Vol. 45, No. 3, 2007, pp. 361-363. doi:10.1097/QAI.0b013e318053754c

[28] N. N. Vijay, Vasantika, R. Ajmani, A. S. Perelson and N. M. Dixit, "Recombination Increases Human Immunodeficiency Virus Fitness, but Not Necessarily Diversity," Journal of General Virology, Vol. 89, Pt. 6, 2008, pp. 14671477. doi:10.1099/vir.0.83668-0

[29] K. Delviks-Frankenberry, A. Galli, O. Nikolaitchik, H. Mens, V. K. Pathak and W. S. Hu, "Mechanisms and Factors That Influence High Frequency Retroviral Recombination,” Viruses, Vol. 3, No. 9, 2011, pp. 1650-1680. doi:10.3390/v3091650

[30] A. C. van der Kuyl and M. Cornelissen, "Identifying HIV1 Dual Infections,” Retrovirology, Vol. 4, 2007, p. 67. doi:10.1186/1742-4690-4-67

[31] A. R. Templeton, M. G. Kramer, J. Jarvis, J. Kowalski, S. Gange, M. F. Schneider, et al., "Multiple-Infection and Recombination in HIV-1 within a Longitudinal Cohort of Women,” Retrovirology, Vol. 6, 2009, p. 54. doi:10.1186/1742-4690-6-54

[32] B. Chohan, L. Lavreys, S. M. Rainwater and J. Overbaugh, "Evidence for Frequent Reinfection with Human Immunodeficiency Virus Type 1 of a Different Subtype," Journal of Virology, Vol. 79, No. 16, 2005, pp. 1070110708. doi:10.1128/JVI.79.16.10701-10708.2005

[33] D. J. Hu, S. Subbarao, S. Vanichseni, P. A. Mock, A. Ramos, L. Nguyen, et al., "Frequency of HIV-1 Dual Subtype Infections, including Intersubtype Superinfections, among Injection Drug Users in Bangkok, Thailand," AIDS, Vol. 19, No. 3, 2005, pp. 303-308.

[34] F. E. McCutchan, M. Hoelscher, S. Tovanabutra, S. Piyasirisilp, E. Sanders-Buell, G. Ramos, et al., "In-Depth Analysis of a Heterosexually Acquired Human Immunodeficiency Virus Type 1 Superinfection: Evolution, Temporal Fluctuation, and Intercompartment Dynamics from the Seronegative Window Period through 30 Months Postinfection," Journal of Virology, Vol. 79, No. 18, 2005, pp. 11693-11704. doi:10.1128/JVI.79.18.11693-11704.2005

[35] K. L. Gross, T. C. Porco and R. M. Grant, "HIV-1 Superinfection and Viral Diversity,” AIDS, Vol. 18, No. 11, 2004, pp. 1513-1520. doi:10.1097/01.aids.0000131361.75328.47

[36] J. C. Plantier, V. Lemee, I. Dorval, M. Gueudin, J. Braun, P. Hutin, et al., "HIV-1 Group M Superinfection in an HIV-1 Group O-Infected Patient,” AIDS, Vol. 18, No. 18, 2004, pp. 2444-2446.

[37] G. S. Gottlieb, D. C. Nickle, M. A. Jensen, K. G. Wong, J. Grobler, F. Li, et al., "Dual HIV-1 Infection Associated with Rapid Disease Progression,” The Lancet, Vol. 363, No. 9409, 2004, pp. 619-622. doi:10.1016/S0140-6736(04)15596-7

[38] T. M. Allen and M. Altfeld, "HIV-1 Superinfection," The Journal of Allergy and Clinical Immunology, Vol. 112,
No. 5, 2003, pp. 829-835. doi:10.1016/j.jaci.2003.08.037

[39] J. Grobler, C. M. Gray, C. Rademeyer, C. Seoighe, G. Ramjee, S. A. Karim, et al., "Incidence of HIV-1 Dual Infection and Its Association with Increased Viral Load Set Point in a Cohort of HIV-1 Subtype C-Infected Female Sex Workers," The Journal of Infectious Diseases, Vol. 190, No. 7, 2004, pp. 1355-1359. doi:10.1086/423940

[40] E. Saathoff, M. Pritsch, C. Geldmacher, O. Hoffmann, R. N. Koehler, L. Maboko, et al., "Viral and Host Factors Associated with the HIV-1 Viral Load Setpoint in Adults from Mbeya Region, Tanzania,” Journal of Acquired Immune Deficiency Syndromes, Vol. 54, No. 3, 2010, pp. 324-330. doi:10.1097/QAI.0b013e3181cf30ba

[41] B. H. Chohan, A. Piantadosi and J. Overbaugh, "HIV-1 Superinfection and Its Implications for Vaccine Design," Current HIV Research, Vol. 8, No. 8, 2010, pp. 596-601. doi:10.2174/157016210794088218

[42] D. D. Ho, A. U. Neumann, A. S. Perelson, W. Chen, J. M. Leonard and M. Markowitz, "Rapid Turnover of Plasma Virions and CD4 Lymphocytes in HIV-1 Infection," $\mathrm{Na}$ ture, Vol. 373, No. 6510, 1995, pp. 123-126. doi:10.1038/373123a0

[43] J. Zhang, "Host RNA Polymerase II Makes Minimal Contributions to Retroviral Frame Shift Mutations," Journal of General Virology, Vol. 85, No. 8, 2004, pp. 23892395. doi:10.1099/vir.0.80081-0

[44] J. Eberle and L. Gurtler, "HIV Types, Groups, Subtypes and Recombinant Forms: Errors in Replication, Selection Pressure and Quasispecies,” Intervirology, Vol. 55, No. 2, 2012, pp. 79-83. doi:10.1159/000331993

[45] P. Jern, R. A. Russell, V. K. Pathak and J. M. Coffin, "Likely Role of APOBEC3G-Mediated G-to-A Mutations in HIV-1 Evolution and Drug Resistance," PloS Pathogens, Vol. 5, No. 4, 2009, e100367. doi:10.1371/journal.ppat.1000367

[46] R. Sampathkumar, E. Shadabi and M. Luo, "Interplay between HIV-1 and Host Genetic Variation: A Snapshot into Its Impact on AIDS and Therapy Response,” $A d$ vances in Virology, Vol. 2012, No. 2012, 2012, Article ID: 508967.

[47] C. Brander, N. Frahm and B. D. Walker, "The Challenges of Host and Viral Diversity in HIV Vaccine Design," Current Opinion in Immunology, Vol. 18, No. 4, 2006, pp. 430-437. doi:10.1016/j.coi.2006.05.012

[48] B. F. Keele, L. Tazi, S. Gartner, Y. Liu, T. B. Burgon, J. D. Estes, et al., "Characterization of the Follicular Dendritic Cell Reservoir of Human Immunodeficiency Virus Type 1,” Journal of Virology, Vol. 82, No. 11, 2008, pp. 5548-5561. doi:10.1128/JVI.00124-08

[49] C. Kuiken, R. Thakallapalli, A. Esklid and R. de Anthony, "Genetic Analysis Reveals Epidemiologic Patterns in the Spread of Human Immunodeficiency Virus,” American Journal of Epidemiology, Vol. 152, No. 9, 2000, pp. 814822. doi:10.1093/aje/152.9.814

[50] S. Wain-Hobson and G. Myers, "Human Immunodeficiency Viruses. Too Close for Comfort,” Nature, Vol. 347, No. 6288, 1990, p. 18.

[51] J. L. Sankale, R. S. De La Tour, R. G. Marlink, R. Scheib, 
S. Mboup, M. E. Essex, et al., "Distinct Quasi-Species in the Blood and the Brain of an HIV-2-Infected Individual,” Virology, Vol. 226, No. 2, 1996, pp. 418-423. doi:10.1006/viro.1996.0671

[52] M. Goodenow, T. Huet, W. Saurin, S. Kwok, J. Sninsky and S. Wain-Hobson, "HIV-1 Isolates Are Rapidly Evolving Quasispecies: Evidence for Viral Mixtures and Preferred Nucleotide Substitutions," Journal of Acquired Immune Deficiency Syndromes, Vol. 2, No. 4, 1989, pp. 344-352.

[53] A. S. Lauring and R. Andino, "Quasispecies Theory and the Behavior of RNA Viruses," PLoS Pathogens, Vol. 6, No. 7, 2010, e1001005. doi:10.1371/journal.ppat.1001005

[54] M. M. Jackson, S. R. Stanley, P. Nelson, D. R. Richardson and G. B. White, "Compendium of HIV/AIDS Positions, Policies and Documents," American Nurses Association Publications, Silver Spring, 1992.

[55] J. Louwagie, W. Janssens, J. Mascola, L. Heyndrickx, P. Hegerich, G. van der Groen, et al., "Genetic Diversity of the Envelope Glycoprotein from Human Immunodeficiency Virus Type 1 Isolates of African Origin,” Journal of Virology, Vol. 69, No. 1, 1995, pp. 263-271.

[56] A. Abebe, G. Pollakis, A. L. Fontanet, B. Fisseha, B. Tegbaru, A. Kliphuis, et al., "Identification of a Genetic Subcluster of HIV Type 1 Subtype C (C') Widespread in Ethiopia," AIDS Research and Human Retroviruses, Vol. 16, No. 17, 2000, pp. 1909-1914. doi:10.1089/08892220050195865

[57] J. Archer and D. L. Robertson, "Understanding the Diversification of HIV-1 Groups M and O,” AIDS, Vol. 21, No. 13, 2007, pp. 1693-1700. doi:10.1097/QAD.0b013e32825eabd0

[58] P. C. Aulicino, J. Kopka, A. M. Mangano, C. Rocco, M. Iacono, R. Bologna, et al., "Circulation of Novel HIV Type 1 A, B/C, and F Subtypes in Argentina,” AIDS Research and Human Retroviruses, Vol. 21, No. 2, 2005, pp. 158-164. doi:10.1089/aid.2005.21.158

[59] I. Bartolo, C. Rocha, J. Bartolomeu, A. Gama, R. Marcelino, M. Fonseca, et al., "Highly Divergent Sub-types and New Recombinant Forms Prevail in the HIV/AIDS Epidemic in Angola: New Insights into the Origins of the AIDS Pandemic," Infection, Genetics and Evolution, Vol. 9, No. 4, 2009, pp. 672-682. doi:10.1016/j.meegid.2008.05.003

[60] H. Bredell, G. Hunt, A. Casteling, T. Cilliers, C. Rademeyer, M. Coetzer, et al., "HIV-1 Subtype A, D, G, AG and Unclassified Sequences Identified in South Africa," AIDS Research and Human Retroviruses, Vol. 18, No. 9, 2002, pp. 681-683. doi:10.1089/088922202760019400

[61] F. Gao, L. Yue, D. L. Robertson, S. C. Hill, H. Hui, R. J. Biggar, et al., "Genetic Diversity of Human Immunodeficiency Virus Type 2: Evidence for Distinct Sequence Subtypes with Differences in Virus Biology," Journal of Virology, Vol. 68, No. 11, 1994, pp. 7433-7447.

[62] A. M. Geretti, "HIV-1 Subtypes: Epidemiology and Significance for HIV Management," Current Opinion in Infectious Diseases, Vol. 19, No. 1, 2006, pp. 1-7. doi:10.1097/01.qco.0000200293.45532.68

[63] R. S. Diaz, L. Zhang, M. P. Busch, J. W. Mosley and A.
Mayer, "Divergence of HIV-1 Quasispecies in an Epidemiologic Cluster,” AIDS, Vol. 11, No. 4, 1997, pp. 415422. doi:10.1097/00002030-199704000-00003

[64] K. Gould, "Infection with HIV-1 Group O,” AIDS Patient Care STDs, Vol. 11, No. 6, 1997, pp. 399-405. doi:10.1089/apc.1997.11.399

[65] P. J. Kanki, M. Peeters and A. Gueye-Ndiaye, "Virology of HIV-1 and HIV-2: Implications for Africa," AIDS, Vol. 11, Suppl B, 1997, pp. S33-S42.

[66] M. A. Pando, L. M. Eyzaguirre, M. Segura, C. T. Bautista, R. Marone, A. Ceballos, et al., "First Report of an HIV-1 Triple Recombinant of Subtypes B, C and F in Buenos Aires, Argentina,” Retrovirology, Vol. 3, 2006, p. 59. doi:10.1186/1742-4690-3-59

[67] B. C. Ramirez, E. Simon-Loriere, R. Galetto and M. Negroin, "Implications of Recombination for HIV Diversity,” Virus Research, Vol. 134, No. 1-2, 2008, pp. 64-73. doi:10.1016/j.virusres.2008.01.007

[68] J. Stebbing and G. Moyle, "The Clades of HIV: Their Origins and Clinical Significance,” AIDS Reviews, Vol. 5, No. 4, 2003, pp. 205-213.

[69] F. E. McCutchan, K. Viputtigul, M. S. de Souza, J. K. Carr, L. E. Markowitz, P. Buapunth, et al., "Diversity of Envelope Glycoprotein from Human Immunodeficiency Virus Type 1 of Recent Seroconverters in Thailand," AIDS Research and Human Retroviruses, Vol. 16, No. 8, 2000, pp. 801-805. doi:10.1089/088922200308792

[70] F. Gao, E. Bailes, D. L. Robertson, Y. Chen, C. M. Rodenburg, S. F. Michael, et al., "Origin of HIV-1 in the Chimpanzee Pan Troglodytes Troglodytes,” Nature, Vol. 397, No. 6718, 1999, pp. 436-441.

[71] B. H. Hahn, G. M. Shaw, K. M. De Cock and P. M. Sharp, "AIDS as a Zoonosis: Scientific and Public Health Implications,” Science, Vol. 287, No. 5453, 2000, pp. 607614. doi:10.1126/science.287.5453.607

[72] B. F. Keele, H. F. Van, Y. Li, E. Bailes, J. Takehisa, M. L. Santiago, et al., "Chimpanzee Reservoirs of Pandemic and Nonpandemic HIV-1,” Science, Vol. 313, No. 5786, 2006, pp. 523-526. doi:10.1126/science.1126531

[73] V. M. Hirsch, R. A. Olmsted, M. Murphey-Corb, R. H. Purcell and P. R. Johnson, "An African Primate Lentivirus $\left(\mathrm{SIV}_{\mathrm{sm}}\right)$ Closely Related to HIV-2,” Nature, Vol. 339, No. 6223, 1989, pp. 389-392. doi:10.1038/339389a0

[74] P. R. Johnson, M. Gravell, J. Allan, S. Goldstein, R. A. Olmsted, G. Dapolito, et al., "Genetic Diversity among Simian Immunodeficiency Virus Isolates from African Green Monkeys,” Journal of Medical Primatology, Vol. 18, No. 3-4, 1989, pp. 271-277.

[75] P. M. Sharp and B. H. Hahn, "Origins of HIV and the AIDS Pandemic," Cold Spring Harbor Perspectives in Medicine, Vol. 1, No. 1, 2011, Article ID: A006841. doi:10.1101/cshperspect.a006841

[76] F. Clavel, M. Guyader, D. Guetard, M. Salle, L. Montagnier and M. Alizon, "Molecular Cloning and Polymorphism of the Human Immune Deficiency Virus Type 2," Nature, Vol. 324, No. 6098, 1986, pp. 691-695. doi:10.1038/324691a0

[77] P. J. Kanki, K. U. Travers, S. Mboup, C. C. Hsieh, R. G. 
Marlink, A. Gueye-Ndiaye, et al., "Slower Heterosexual Spread of HIV-2 than HIV-1,” The Lancet, Vol. 343, No. 8903, 1994, pp. 943-946. doi:10.1016/S0140-6736(94)90065-5

[78] R. Marlink, P. Kanki, I. Thior, K. Travers, G. Eisen, T. Siby, et al., "Reduced Rate of Disease Development after HIV-2 Infection as Compared to HIV-1,” Science, Vol. 265, No. 5178, 1994, pp. 1587-1590. doi:10.1126/science.7915856

[79] C. A. Adje-Toure, R. Cheingsong, J. G. Garcia-Lerma, S. Eholie, M. Y. Borget, J. M. Bouchez, et al., "Antiretroviral Therapy in HIV-2-Infected Patients: Changes in Plasma Viral Load, CD4 ${ }^{+}$Cell Counts, and Drug Resistance Profiles of Patients Treated in Abidjan, Cote d'Ivoire,” AIDS, Vol. 17, Suppl. 3, 2003, pp. S49-S54. doi:10.1097/00002030-200317003-00007

[80] K. Motomura, J. Chen and W. S. Hu, "Genetic Recombination between Human Immunodeficiency Virus Type 1 (HIV-1) and HIV-2, Two Distinct Human Lentiviruses,” Journal of Virology, Vol. 82, No. 4, 2008, pp. 1923-1933. doi:10.1128/JVI.01937-07

[81] S. Locatelli and M. Peeters, "Cross-Species Transmission of Simian Retroviruses: How and Why They Could Lead to the Emergence of New Diseases in the Human Population,” AIDS, Vol. 26, No. 6, 2012, pp. 659-673. doi:10.1097/QAD.0b013e328350fb68

[82] B. Korber, M. Muldoon, J. Theiler, F. Gao, R. Gupta, A. Lapedes, et al., "Timing the Ancestor of the HIV-1 Pandemic Strains,” Science, Vol. 288, No. 5472, 2000, pp. 1789-1796. doi:10.1126/science.288.5472.1789

[83] H. X. Liao, L. L. Sutherland, S. M. Xia, M. E. Brock, R. M. Scearce, S. Vanleeuwen, et al., "A Group M Consensus Envelope Glycoprotein Induces Antibodies that Neutralize Subsets of Subtype B and C HIV-1 Primary Viruses,” Virology, Vol. 353, No. 2, 2006, pp. 268-282. doi:10.1016/j.virol.2006.04.043

[84] T. Zhu, B. T. Korber, A. J. Nahmias, E. Hooper, P. M. Sharp and D. D. Ho, "An African HIV-1 Sequence from 1959 and Implications for the Origin of the Epidemic," Nature, Vol. 391, No. 6667, 1998, pp. 594-597.

[85] D. L. Robertson, J. P. Anderson, J. A. Bradac, J. K. Carr, B. Foley, R. K. Funkhouser, et al., "HIV-1 Nomenclature Proposal,” Science, Vol. 288, No. 5463, 2000, pp. 55-56. doi:10.1126/science.288.5463.55d

[86] J. C. Plantier, M. Leoz, J. E. Dickerson, F. De Oliveira, F. Cordonnier, V. Lemee, et al., "A New Human Immunodeficiency Virus Derived from Gorillas,” Nature Medicine, Vol. 15, No. 8, 2009, pp. 871-872.

[87] J. Takehisa, M. H. Kraus, A. Ayouba, E. Bailes, H. F. Van, J. M. Decker, et al., "Origin and Biology of Simian Immunodeficiency Virus in Wild-Living Western Gorillas," Journal of Virology, Vol. 83, No. 4, 2009, pp. 16351648. doi:10.1128/JVI.02311-08

[88] A. Vallari, V. Holzmayer, B. Harris, J. Yamaguchi, C. Ngansop, F. Makamche, et al., "Confirmation of Putative HIV-1 Group P in Cameroon,” Journal of Virology, Vol. 85, No. 3, 2011, pp. 1403-1407. doi:10.1128/JVI.02005-10
[89] M. O. Salminen, C. Koch, E. Sanders-Buell, P. K. Ehrenberg, N. L. Michael, J. K. Carr, et al., "Recovery of Virtually Full-Length HIV-1 Provirus of Diverse Subtypes from Primary Virus Cultures Using the Polymerase Chain Reaction,” Virology, Vol. 213, No. 1, 1995, pp. 80-86. doi:10.1006/viro.1995.1548

[90] J. Hemelaar, E. Gouws, P. D. Ghys and S. Osmanov, "Global and Regional Distribution of HIV-1 Genetic Subtypes and Recombinants in 2004,” AIDS, Vol. 20, No. 16, 2006, pp. W13-W23. doi:10.1097/01.aids.0000247564.73009.bc

[91] T. D. Mastro, C. Kunanusont, T. J. Dondero and C. Wasi, "Why Do HIV-1 Subtypes Segregate among Persons with Different Risk Behaviors in South Africa and Thailand?” AIDS, Vol. 11, No. 1, 1997, pp. 113-116. doi:10.1097/00002030-199701000-00017

[92] H. J. Van, R. Wood, M. Lambrick, E. P. Rybicki, A. L. Williamson and C. Williamson, "An Association between HIV-1 Subtypes and Mode of Transmission in Cape Town, South Africa,” AIDS, Vol. 11, No. 1, 1997, pp. 81-87. doi:10.1097/00002030-199701000-00012

[93] J. Louwagie, F. McCutchan, G. van der Groen, M. Peeters, K. Fransen, P. Piot, et al., "Genetic Comparison of HIV-1 Isolates from Africa, Europe, and North America,” AIDS Research and Human Retroviruses, Vol. 8, No. 8, 1992, pp. 1467-1469.

[94] K. Triques, A. Bourgeois, N. Vidal, E. Mpoudi-Ngole, C. Mulanga-Kabeya, N. Nzilambi, et al., "Near-Full-Length Genome Sequencing of Divergent African HIV Type 1 Subtype F Viruses Leads to the Identification of a New HIV Type 1 Subtype Designated K," AIDS Research and Human Retroviruses, Vol. 16, No. 2, 2000, pp. 139-151. doi:10.1089/088922200309485

[95] S. T. Meloni, B. Kim, J. L. Sankale, D. J. Hamel, S. Tovanabutra, S. Mboup, et al., "Distinct Human Immunodeficiency Virus Type 1 Subtype A Virus Circulating in West Africa: Sub-Subtype A3,” Journal of Virology, Vol. 78, No. 22, 2004, pp. 12438-12445. doi:10.1128/JVI.78.22.12438-12445.2004

[96] J. K. Carr, M. O. Salminen, J. Albert, E. Sanders-Buell, D. Gotte, D. L. Birx, et al., "Full Genome Sequences of Human Immunodeficiency Virus Type 1 Subtypes G and A/G Intersubtype Recombinants,” Virology, Vol. 247, No. 1, 1998, pp. 22-31. doi:10.1006/viro.1998.9211

[97] M. M. Thomson and R. Najera, "Molecular Epidemiology of HIV-1 Variants in the Global AIDS Pandemic: An Update," AIDS Reviews, Vol. 7, No. 4, 2005, pp. 210 224.

[98] F. Gao, D. L. Robertson, S. G. Morrison, H. Hui, S. Craig, J. Decker, et al., "The Heterosexual Human Immunodeficiency Virus Type 1 Epidemic in Thailand Is Caused by an Intersubtype (A/E) Recombinant of African Origin," Journal of Virology, Vol. 70, No. 10, 1996, pp. 70137029.

[99] G. Casado, M. M. Thomson, M. Sierra and R. Najera, "Identification of a Novel HIV-1 Circulating ADG Intersubtype Recombinant Form (CRF19_cpx) in Cuba," Journal of Acquired Immune Deficiency Syndromes, Vol. 40, No. 5, 2005, pp. 532-537. 


\section{doi:10.1097/01.qai.0000186363.27587.c0}

[100] J. Hemelaar, E. Gouws, P. D. Ghys and S. Osmanov, "Global and Regional Distribution of HIV-1 Genetic Subtypes and Recombinants in 2004,” AIDS, Vol. 20, No. 16, 2006, pp. W13-W23. doi:10.1097/01.aids.0000247564.73009.bc

[101] J. R. Neilson, G. C. John, J. K. Carr, P. Lewis, J. K. Kreiss, S. Jackson, et al., "Subtypes of Human Immunodeficiency Virus Type 1 and Disease Stage among Women in Nairobi, Kenya," Journal of Virology, Vol. 73, No. 5, 1999, pp. 4393-4403.

[102] M. A. Montano, C. P. Nixon, T. Ndung'u, H. Bussmann, V. A. Novitsky, D. Dickman, et al., "Elevated Tumor Necrosis Factor-alpha Activation of Human Immunodeficiency Virus Type 1 Subtype C in Southern Africa Is Associated with an NF-kappaB Enhancer Gain-Of-Function,” The Journal of Infectious Diseases, Vol. 181, No. 1, 2000, pp. 76-81.doi:10.1086/315185

[103] J. T. Blackard, B. Renjifo, W. Fawzi, E. Hertzmark, G. Msamanga, D. Mwakagile, et al., "HIV-1 LTR Subtype and Perinatal Transmission," Virology, Vol. 287, No. 2, 2001, pp. 261-265. doi:10.1006/viro.2001.1059

[104] B. Renjifo, W. Fawzi, D. Mwakagile, D. Hunter, G. Msamanga, D. Spiegelman, et al., "Differences in Perinatal Transmission among Human Immunodeficiency Virus Type 1 Genotypes,” Journal of Human Virology, Vol. 4, No. 1, 2001, pp. 16-25.

[105] G. N. Odaibo, E. Donbraye, M. O. Adewumi, A. S. Bakarey, M. A. Ibeh and D. O. Olaleye, "Reliability of Testing and Potential Impact on HIV Prevention in Nigeria," African Journal of Medicine and Medical Sciences, Vol. 35, 2006, pp. S131-S135.

[106] G. Nabel, W. Makgoba and J. Esparza, "HIV-1 Diversity and Vaccine Development,” Science, Vol. 296, No. 5577, 2002, p. 2335. doi:10.1126/science.296.5577.2335

[107] J. M. Coffin, "HIV Population Dynamics in Vivo: Implications for Genetic Variation, Pathogenesis, and Therapy,” Science, Vol. 267, No. 5197, 1995, pp. 483-489. doi:10.1126/science.7824947

[108] Y. Shao and C. Williamson, "The HIV-1 Epidemic: Lowto Middle-Income Countries," Cold Spring Harbor Perspectives in Medicine, Vol. 2, No. 3, 2012, Article ID: A007187. doi:10.1101/cshperspect.a007187

[109] J. Hemelaar, E. Gouws, P. D. Ghys and S. Osmanov, "Global Trends in Molecular Epidemiology of HIV-1 during 2000-2007,” AIDS, Vol. 25, No. 5, 2011, pp. 679689. doi:10.1097/QAD.0b013e328342ff93

[110] M. Batra, P. C. Tien, R. W. Shafer, C. H. Contag and D. A. Katzenstein, "HIV Type 1 Envelope Subtype C Sequences from Recent Seroconverters in Zimbabwe," AIDS Research and Human Retroviruses, Vol. 16, No. 10, 2000 , pp. 973-979. doi:10.1089/08892220050058399

[111] P. C. Tien, T. Chiu, A. Latif, S. Ray, M. Batra, C. H. Contag, et al., "Primary Subtype C HIV-1 Infection in Harare, Zimbabwe," Journal of Acquired Immune Deficiency Syndromes \& Human Retrovirology, Vol. 20, No. 2, 1999, pp. 147-153. doi:10.1097/00042560-199902010-00006
[112] H. Guevara, E. Johnston, L. Zijenah, O. Tobaiwa, P. Mason, C. Contag, et al., "Prenatal Transmission of Subtype C HIV-1 in Zimbabwe: HIV-1 RNA and DNA in Maternal and Cord Blood," Journal of Acquired Immune Deficiency Syndromes, Vol. 25, No. 5, 2000, pp. 390-397. doi:10.1097/00126334-200012150-00002

[113] S. C. Dalai, T. De Oliveira, G. W. Harkins, S. G. Kassaye, J. Lint, J. Manasa, et al., "Evolution and Molecular Epidemiology of Subtype C HIV-1 in Zimbabwe," AIDS, Vol. 23, No. 18, 2009, pp. 2523-2532. doi:10.1097/QAD.0b013e3283320ef3

[114] B. L. Walter, A. E. Armitage, S. C. Graham, T. De Oliveira, P. Skinhoj, E. Y. Jones, et al., "Functional Characteristics of HIV-1 Subtype C Compatible with Increased Heterosexual Transmissibility,” AIDS, Vol. 23, No. 9, 2009, pp. 1047-1057. doi:10.1097/QAD.0b013e32832a1806

[115] T. Ndung'u, Y. Lu, B. Renjifo, N. Touzjian, N. Kushner, V. Pena-Cruz, et al., "Infectious Simian/Human Immunodeficiency Virus with Human Immunodeficiency Virus Type 1 Subtype $\mathrm{C}$ from an African Isolate: Rhesus Macaque Model,” Journal of Virology, Vol. 75, No. 23, 2001, pp. 11417-11425. doi:10.1128/JVI.75.23.11417-11425.2001

[116] S. Osmanov, C. Pattou, N. Walker, B. Schwardlander and J. Esparza, "Estimated Global Distribution and Regional Spread of HIV-1 Genetic Subtypes in the Year 2000," Journal of Acquired Immune Deficiency Syndromes, Vol. 29, No. 2, 2002, pp. 184-190.

[117] P. Gupta, K. B. Collins, D. Ratner, S. Watkins, G. J. Naus, D. V. Landers, et al., "Memory $\mathrm{CD}^{+} \mathrm{T}$ Cells Are the Earliest Detectable Human Immunodeficiency Virus Type 1 (HIV-1)-Infected Cells in the Female Genital Mucosal Tissue during HIV-1 Transmission in an Organ Culture System,” Journal of Virology, Vol. 76, No. 19, 2002, pp. 9868-9876. doi:10.1128/JVI.76.19.9868-9876.2002

[118] J. T. Herbeck, D. C. Nickle, G. H. Learn, G. S. Gottlieb, M. E. Curlin, L. Heath, et al., "Human Immunodeficiency Virus Type 1 env Evolves toward Ancestral States upon Transmission to a New Host," Journal of Virology, Vol. 80, No. 4, 2006, pp. 1637-1644. doi:10.1128/JVI.80.4.1637-1644.2006

[119] M. Sagar, O. Laeyendecker, S. Lee, J. Gamiel, M. J. Wawer, R. H. Gray, et al., "Selection of HIV Variants with Signature Genotypic Characteristics during Heterosexual Transmission," The Journal of Infectious Diseases, Vol. 199, No. 4, 2009, pp. 580-589. doi:10.1086/596557

[120] S. H. Eshleman, Y. Lie, D. R. Hoover, S. Chen, S. E. Hudelson, S. A. Fiscus, et al., "Association between the Replication Capacity and Mother-to-Child Transmission of HIV1, in Antiretroviral Drug-Naive Malawian Women," The Journal of Infectious Diseases, Vol. 193, No. 11, 2006, pp. 1512-1515. doi:10.1086/503810

[121] J. R. Lingappa, J. P. Hughes, R. S. Wang, J. M. Baeten, C. Celum, G. E. Gray, et al., "Estimating the Impact of Plasma HIV-1 RNA Reductions on Heterosexual HIV-1 Transmission Risk,” PLoS One, Vol. 5, No. 9, 2010, e12598. doi:10.1371/journal.pone.0012598 
[122] M. Essex, L. E. Soto-Ramirez, E. Renjifo, W. K. Wang, T. H. Lee, "Genetic Variation within Human Immunodeficiency Viruses Generates Rapid Changes in Tropism, Virulence, and Transmission,” Leukemia, Vol. 11, Suppl. 3, 1997, pp. 93-94.

[123] N. Kiwanuka, O. Laeyendecker, T. C. Quinn, M. J. Wawer, J. Shepherd, M. Robb, et al., "HIV-1 Subtypes and Differences in Heterosexual HIV Transmission among HIVDiscordant Couples in Rakai, Uganda," AIDS, Vol. 23, No. 18, 2009, pp. 2479-2484. doi:10.1097/QAD.0b013e328330cc08

[124] B. L. Guthrie, G. de Bruyn and C. Farquhar, "HIV-1-Discordant Couples in Sub-Saharan Africa: Explanations and Implications for High Rates of Discordancy,” Current HIV Research, Vol. 5, No. 4, 2007, pp. 416-429. doi:10.2174/157016207781023992

[125] P. R. Mehta, S. Nema, S. Paranjpe, N. Ingole, S. Wanjare and G. Nataraj, "Study of HIV-1 Subtypes in Serodiscordant Couples Attending an Integrated Counselling and Testing Centre in Mumbai Using Heteroduplex Mobility Analysis and DNA Sequencing," Indian Journal of Medical Microbiology, Vol. 28, No. 4, 2010, pp. 290-294. doi:10.4103/0255-0857.71807

[126] R. M. Troyer, K. R. Collins, A. Abraha, E. Fraundorf, D. M. Moore, R. W. Krizan, et al., "Changes in Human Immunodeficiency Virus Type 1 Fitness and Genetic Diversity during Disease Progression," Journal of Virology, Vol. 79, No. 14, 2005, pp. 9006-9018. doi:10.1128/JVI.79.14.9006-9018.2005

[127] D. Archary, M. L. Gordon, T. N. Green, H. M. Coovadia, P. J. Goulder and T. Ndung'u, "HIV-1 Subtype C Envelope Characteristics Associated with Divergent Rates of Chronic Disease Progression,” Retrovirology, Vol. 7, 2010, p. 92. doi:10.1186/1742-4690-7-92

[128] P. J. Kanki, D. J. Hamel, J. L. Sankale, C. Hsieh, I. Thior, F. Barin, et al., "Human Immunodeficiency Virus Type 1 Subtypes Differ in Disease Progression,” The Journal of Infectious Diseases, Vol. 179, No. 1, 1999, pp. 68-73. doi:10.1086/314557

[129] A. Vasan, B. Renjifo, E. Hertzmark, B. Chaplin, G. Msamanga, M. Essex, et al., "Different Rates of Disease Progression of HIV Type 1 Infection in Tanzania Based on Infecting Subtype," Clinical Infectious Diseases, Vol. 42, No. 6, 2006, pp. 843-852. doi:10.1086/499952
[130] P. Kaleebu, N. French, C. Mahe, D. Yirrell, C. Watera, F. Lyagoba, et al., "Effect of Human Immunodeficiency Virus (HIV) Type 1 Envelope Subtypes A and D on Disease Progression in a Large Cohort of HIV-1-Positive Persons in Uganda," The Journal of Infectious Diseases, Vol. 185, No. 9, 2002, pp. 1244-1250. doi:10.1086/340130

[131] N. Kiwanuka, O. Laeyendecker, M. Robb, G. Kigozi, M. Arroyo, F. McCutchan, et al., "Effect of Human Immunodeficiency Virus Type 1 (HIV-1) Subtype on Disease Progression in Persons from Rakai, Uganda, with Incident HIV-1 Infection,” The Journal of Infectious Diseases, Vol. 197, No. 5, 2008, pp. 707-713. doi:10.1086/527416

[132] N. R. Mugo, M. Med, R. Heffron, D. Donnell, A. Wald, E. O. Were, et al., "Increased Risk of HIV-1 Transmission in Pregnancy: A Prospective Study among African HIV-1 Serodiscordant Couples,” AIDS, Vol. 25, No. 15, 2011, pp. 1887-1895. doi:10.1097/QAD.0b013e32834a9338

[133] G. C. John-Stewart, R. W. Nduati, C. M. Rousseau, D. A. Mbori-Ngacha, B. A. Richardson, S. Rainwater, et al., "Subtype C Is Associated with Increased Vaginal Shedding of HIV-1,” The Journal of Infectious Diseases, Vol. 192, No. 3, 2005, pp. 492-496. doi:10.1086/431514

[134] L. A. Panther, L. Tucker, C. Xu, R. E. Tuomala, J. I. Mullins and D. J. Anderson, "Genital Tract Human Immunodeficiency Virus Type 1 (HIV-1) Shedding and Inflammation and HIV-1 env Diversity in Perinatal HIV-1 Transmission," The Journal of Infectious Diseases, Vol. 181, No. 2, 2000, pp. 555-563. doi:10.1086/315230

[135] E. L. Delwart, E. G. Shpaer, J. Louwagie, F. E. McCutchan, M. Grez, H. Rubsamen-Waigmann, et al., "Genetic Relationships Determined by a DNA Heteroduplex Mobility Assay: Analysis of HIV-1 env Genes," Science, Vol. 262, No. 5137, 1993, pp. 1257-1261. doi:10.1126/science.8235655

[136] L. Heyndrickx, W. Janssens, L. Zekeng, R. Musonda, S. Anagonou, G. Van der Auwera, et al., "Simplified Strategy for Detection of Recombinant Human Immunodeficiency Virus Type 1 Group M Isolates by gag/env Heteroduplex Mobility Assay. Study Group on Heterogeneity of HIV Epidemics in African Cities,” Journal of Virology, Vol. 74, No. 1, 2000, pp. 363-370. doi:10.1128/JVI.74.1.363-370.2000 